\title{
PENYELESAIAN TUNTUTAN GANTI KERUGIAN NEGARA/DAERAH TERHADAP PEGAWAI NEGERI BUKAN BENDAHARA DAN PEJ ABAT LAIN
}

\author{
Henny J uliani \\ Fakultas Hukum Universitas Diponegoro \\ hennyjuliani.fhundip@gmail.com
}

\begin{abstract}
ABSTRAK
Penelitian ini bertujuan untuk mengetahui penyelesaian kerugian keuangan negara/daerah terhadap pegawai negeri bukan bendahara atau pejabat lain yang karena perbuatannya menimbulkan kerugian negara/daerah. Metoda penelitian yang digunakan adalah yuridis normatif dengan menggunakan pendekatan deskriptif analitis. Hasil penelitian menemukan bahwa terhadap pegawai negeri bukan bendahara atau pejabat lain dapat dikenai tuntutan ganti kerugian negara/daerah apabila perbuatannya dilakukan secara melanggar hukum atau karena kelalaian yang secara langsung menimbulkan kerugian keuangan negara/daerah, sehingga wajib mengganti kerugian tersebut. Tuntutan ganti kerugian tersebut bertujuan untuk memulihkan kerugian negara/daerah. Di ranah Hukum Administrasi Negara hal tersebut diatur dalam Undang-Undang Nomor 17 Tahun 2003, Undang-Undang Nomor 1 Tahun 2004, dan Peraturan Pemerintah Nomor 38 Tahun 2016. Pegawai negeri bukan bendahara atau pejabat lain yang telah ditetapkan untuk mengganti kerugian negara/daerah dapat dikenai sanksi administratif dan/atau sanksi pidana. Putusan pidana tidak membebaskan dari tuntutan ganti rugi.
\end{abstract}

\section{Kata Kunci: Pegawai Negeri Bukan Bendahara atau Pejabat Lain; Tuntutan Ganti Kerugian Negara/Daerah}

\section{A. PENDAHULUAN}

\section{Latar Belakang Permasalahan}

Undang-Undang Dasar Negara Republik Indonesia Tahun 1945 Pasal 4 ayat (1) memberikan kewenangan kepada Presiden dalam menjalankan kekuasaan pemerintahan untuk mencapai tujuan bernegara, yaitu menyejahterakan rakyat. Amanah Konstitusi yang diberikan kepada Presiden tersebut dijabarkan lebih lanjut dalam Pasal 6 ayat (1) Undang-Undang Nomor 17 Tahun 2003 tentang Keuangan Negara yang menyatakan bahwa Presiden selaku Kepala Pemerintahan memegang kekuasaan pengelolaan keuangan negara sebagai bagian dari kekuasaan pemerintahan.

Kekuasaan atas pengelolaan keuangan negara yang dipegang oleh Presiden tersebut meliputi kewenangan yang bersifat umum dan kewenangan yang bersifat khusus. Kewenangan yang bersifat umum meliputi penetapan arah, kebijakan umum, strategi dan prioritas dalam pengelolaan APBN, antara lain penetapan 
Jurnal Law Reform

Volume 13, Nomor 2, Tahun 2017
Program Studi Magister Ilmu Hukum Fakultas Hukum Universitas Diponegoro pedoman penyusunan rencana kerja kementerian negara/lembaga, penetapan gaji dan tunjangan, serta pedoman pengelolaan penerimaan negara. Kewenangan yang bersifat khusus meliputi keputusan/kebijakan teknis yang berkaitan dengan pengelolaan APBN, antara lain keputusan sidang kabinet di bidang pengelolaan APBN, keputusan rincian APBN, keputusan dana perimbangan, dan penghapusan aset dan piutang negara.

Penjelasan Umum Undang-Undang Nomor 17 Tahun 2003 tentang Keuangan Negara menyatakan bahwa untuk membantu Presiden dalam penyelenggaraan kekuasaan tersebut, sebagian dari kekuasaan tersebut dikuasakan kepada Menteri Keuangan selaku Pengelola Fiskal dan Wakil Pemerintah dalam kepemilikan kekayaan negara yang dipisahkan, serta kepada Menteri/Pimpinan Lembaga selaku Pengguna Anggaran/Pengguna Barang kementerian negara/lembaga yang dipimpinnya. Menteri Keuangan sebagai pembantu Presiden dalam bidang keuangan pada hakikatnya adalah Chief Financial Officer (CFO) Pemerintah Republik Indonesia, sementara setiap menteri/pimpinan lembaga pada hakikatnya adalah Chief Operational Officer (COO) untuk suatu bidang tertentu pemerintahan. Prinsip ini perlu dilaksanakan secara konsisten agar terdapat kejelasan dalam pembagian wewenang dan tanggung jawab, terlaksananya mekanisme checks and balances serta untuk mendorong upaya peningkatan profesionalisme dalam penyelenggaraan tugas pemerintahan.

Sesuai dengan asas desentralisasi dalam penyelenggaraan pemerintahan negara sebagian kekuasaan Presiden tersebut diserahkan kepada Gubernur/Bupati/Walikota selaku pengelola keuangan daerah. Oleh karena itu maka kekuasaan atas pengelolaan keuangan negara yang dimiliki Presiden juga dikelola oleh pihak-pihak sebagaimana diatur dalam Pasal 6 ayat (2) Undang-Undang Nomor 17 Tahun 2003 tentang Keuangan Negara.

Pengelolaan keuangan negara harus dapat dipertanggungjawabkan, sehingga Pasal 35 ayat (1) Undang-Undang Nomor 17 Tahun 2003 tentang Keuangan Negara menyatakan bahwa: "Setiap pejabat negara dan pegawai negeri bukan bendahara yang melanggar hukum atau melalaikan kewajibannya baik langsung atau tidak langsung yang merugikan keuangan negara diwajibkan mengganti kerugian dimaksud."

Berkaitan dengan hal tersebut, maka dilakukan penelitian dengan judul: "Penyelesaian Tuntutan Ganti Kerugian Negara/Daerah terhadap Pegawai Negeri Bukan Bendahara atau

\section{Pejabat Lain."}

Hal yang ingin diketahui dalam penelitian ini adalah tentang tata cara tuntutan ganti kerugian keuangan Negara/daerah terhadap pegawai negeri bukan bendahara atau pejabat lain menurut peraturan perundang-undangan. 


\section{Metode Penelitian}

Penelitian ini merupakan penelitian hukum, yang mengkaji dari sudut pandang hukum dengan menggunakan pendekatan yuridis normatif, karena masalah yang akan diteliti tersebut berhubungan erat dengan law in books. Penelitian hukum normatif merupakan penelitian kepustakaan, yaitu penelitian yang dilakukan dari data sekunder. Menurut Ronny Hanitijo Soemitro, data sekunder di bidang hukum (dipandang dari sudut kekuatan mengikatnya), dapat dibedakan menjadi bahanbahan hukum primer, bahan-bahan hukum sekunder, dan bahan hukum tersier ${ }^{1}$. Oleh karena itu maka spesifikasi penelitian yang digunakan adalah deskriptif analitis, yang selanjutnya bahanbahan tersebut akan dianalisis secara kualitatif.

\section{Kerangka Teori}

\section{a. Konsep Negara Kesejahteraan}

Indonesia menganut konsep negara hukum baru yang lebih dinamis yakni yang dikenal dengan istilah welfare state (negara kesejahteraan) atau negara hukum materiil. Di dalam welfare state pemerintah itu diserahi bestuurzorg yaitu penyelenggaraan kesejahteraan umum. ${ }^{2}$ Berkaitan dengan konsep negara kesejahteraan yang merupakan revisi dari konsep negara pasif, Asshiddiqie sebagaimana dikutip oleh W Riawan

1 Ronny Hanityo Soemitro, 1994, Metodologi Penelitian Hukum dan Yurimetri, Jakarta, Ghalia Indonesia, hlm 11 12

2 SF Marbun dan Moh. Mahfud MD, 1987, Pokok-pokok Hukum Administrasi Negara, Yogyakarta, Liberty, hlm 45
Tjandra menguraikan bahwa dalam konsep negara kesejahteraan ini, negara dituntut untuk memperluas tanggung jawabnya kepada masalahmasalah sosial ekonomi yang dihadapi rakyat banyak. ${ }^{3}$

Soekanto dalam W. Riawan Tjandra menyatakan apabila semula negara hanya dipandang sebagai instrument of power, maka mulai timbul aliran-aliran yang menganggap negara sebagai agency of service, maka timbullah konsep welfare state yang terutama memandang manusia tidak hanya sebagai individu, akan tetapi juga sebagai anggota atau warga dari kolektiva dan bahwa manusia bukanlah semata-mata merupakan alat kepentingan kolektiva akan tetapi juga untuk tujuan diri sendiri. ${ }^{4}$

Dalam konsep negara kesejahteraan, negara berperan aktif mencampuri segala aspek kehidupan sosial ekonomi masyarakat dan tidak terbatas hanya pada perlindungan terhadap jiwa dan harta bendanya saja. Oleh karena itu negara membutuhkan sumber-sumber pendapatan yang dapat digunakan bagi pengeluaran/belanja negara dalam rangka melaksanakan peran aktif negara terhadap rakyatnya.

3 W Riawan Tjandra, 2008, Hukum Administrasi Negara, Yogyakarta, Penerbit Universitas Atma Jaya, hlm 9. Ibid, hlm 11-12 


\section{b. Pertanggungjawaban Pejabat dalam Pelaksanaan Fungsi J abatan}

Menurut Philipus M. Hadjon, tanggung jawab pejabat dalam melaksanakan fungsinya dibedakan antara tanggung jawab jabatan dan tanggung jawab pribadi. Tanggung jawab jabatan berkenaan dengan legalitas (keabsahan) tindak pemerintahan. Tanggung jawab pribadi berkenaan dengan maladministrasi dalam penggunaan wewenang maupun public service. Pembedaan antara tanggung jawab jabatan dan tanggung jawab pribadi atas tindak pemerintahan membawa konsekuensi yang berkaitan dengan tanggung jawab pidana, tanggung gugat perdata dan tanggung gugat tata usaha negara (TUN). Tanggung jawab pidana adalah tanggung jawab pribadi. 5 .

Mencermati delik pidana penyalahgunaan kewenangan, kesempatan atau sarana yang ada karena jabatan yang dapat merugikan keuangan negara, Hernold Ferry Makawimbang menyatakan bahwa kata kunci yang harus dijawab adalah "apa kewenangan itu, dan bagaimana kesempatan atau sarana yang ada karena jabatan itu", sehingga dapat disalahgunakan dan dapat merugikan keuangan negara. Jika dilihat dari kata-kata tersebut mempunyai pengertian "kewenangan yang

5 Philipus M. Hadjon dkk, Op. Cit., hlm 16-17. diperoleh karena jabatan" dan jabatan tersebut mempunyai akses terhadap keuangan negara. ${ }^{6}$

Menurut Dian Puji N. Simatupang, luasnya cakupan keuangan negara dalam Pasal 2 UndangUndang Nomor 17 Tahun 2003 dan Penjelasan Pasal 1 Undang-Undang Nomor 31 Tahun 1999 menyebabkan meluasnya cakupan kerugian negara, baik kerugian negara sebagai badan hukum publik maupun negara sebagai badan hukum privat. Dalam hal ini kerugian negara diformulasikan sebagai kekurangan uang, surat berharga, dan barang tanpa melihat asal usul terjadinya kerugian negara tersebut. ${ }^{7}$

Kerugian negara sebagai kekurangan uang, barang, dan surat berharga yang pasti dan nyata sebagai akibat perbuatan melawan hukum atau kelalaian menurut Pasal 1 angka 22 UndangUndang Nomor 1 Tahun 2004 tentang Perbendaharaan Negara, hakikatnya mempunyai hakikat (wadelijk) sebagai berikut: ${ }^{8}$

1) Kerugian hanya merupakan kekurangan atas uang, barang, dan surat berharga;

2) Pasti, maksudnya uang, barang dan surat berharga yang berkurang telah dipastikan jumlahnya melalui pemeriksaan laporan keuangan;

$6 \quad$ Hernold Ferry Makawimbang, 2014, Kerugian Keuangan Negara, Yogyakarta, Thafa Media, hlm 38.

7 Dian Puji N. Simatupang, 2011, Paradoks Rasionalitas Perluasan Ruang Lingkup Keuangan Negara dan Implikasinya terhadap Kinerja Keuangan Pemerintah, Jakarta, Badan Penerbit FHUI, hlm. 328

8 ibid, hlm. 330-331 
3) Nyata, maksudnya uang, barang, dan surat berharga yang berkurang tersebut nyata telah menjadi hak dan/atau kewajiban negara;

4) Berkurangnya disebabkan karena perbuatan melawan hukum (pidana/perdata) atau kelalaian (administrasi negara).

Menurut Agus Ngadino dan Iza Rumesten $\mathrm{RS}$, dalam prakteknya, pengelola pemerintahan baik di pusat maupun di daerah yang melakukan tindakan melawan hukum dan mengakibatkan kerugian negara/daerah dapat dikenakan penggantian atas kerugian negara dimaksud. Dalam bidang pemerintahan pihak yang dapat menjadi subyek penggantian kerugian negara/daerah adalah pihak yang mempunyai kewenangan terkait dengan pengelolaan keuangan negara meliputi Presiden, menteri keuangan, menteri/pimpinan lembaga, kepala daerah, bendahara, pegawai negeri bukan bendahara, dan pejabat lain yang mendapat kewenangan dalam pengelolaan keuangan negara/daerah. Berdasarkan kewenangan yang diberikan menurut ketentuan hukum administrasi, dimana menurut hukum administrasi dikenal tiga cara memperoleh wewenang yaitu atribusi, delegasi, dan mandat.

\section{B. HASIL DAN PEMBAHASAN}

1. Terminologi Keuangan Negara dan Kerugian Keuangan Negara menurut Peraturan Perundang-undangan

\section{a. Terminologi Keuangan Negara}

Terminologi keuangan negara menurut Undang-undang Nomor 17 Tahun 2003 tentang Keuangan Negara dapat dilihat dalam rumusan Pasal 1 angka 1, bahwa yang dimaksud dengan keuangan negara adalah "semua hak dan kewajiban negara yang dapat dinilai dengan uang, serta segala sesuatu baik berupa uang maupun berupa barang yang dapat dijadikan milik negara berhubung dengan pelaksanaan hak dan kewajiban tersebut."

Selanjutnya menurut Pasal 2 UndangUndang Nomor 17 Tahun 2003 tentang Keuangan Negara, Keuangan Negara sebagaimana dimaksud dalam Pasal 1 angka 1 meliputi:

Keuangan Negara sebagaimana dimaksud dalam Pasal 1 angka 1, meliputi :

a. hak negara untuk memungut pajak, mengeluarkan dan mengedarkan uang, dan melakukan pinjaman;

b. kewajiban negara untuk menyelenggarakan tugas layanan umum pemerintahan negara dan membayar tagihan pihak ketiga;

c. Penerimaan Negara;

d. Pengeluaran Negara;

e. Penerimaan Daerah;

f. Pengeluaran Daerah; 
Jurnal Law Reform

Volume 13, Nomor 2, Tahun 2017
Program Studi Magister Ilmu Hukum Fakultas Hukum Universitas Diponegoro
Terminologi keuangan negara menurut Undang-Undang Nomor 31 Tahun 1999 juncto Undang-Undang Nomor 20 Tahun 2001 tentang Pemberantasan Tindak Pidana Korupsi, diatur dalam Penjelasan Umum Undang-undang Nomor 31 Tahun 1999 yang menyatakan bahwa keuangan negara yang dimaksud adalah seluruh kekayaan negara dalam bentuk apapun, yang dipisahkan atau yang tidak dipisahkan, termasuk di dalamnya segala bagian kekayaan negara dan segala hak dan kewajiban yang timbul karena:

a) Berada dalam penguasaan, pengurusan, dan pertanggungjawaban pejabat lembaga negara, baik di tingkat pusat maupun di daerah;

b) Berada dalam penguasaan, pengurusan, dan pertanggungjawaban Badan Usaha Milik Negara/Badan Usaha Milik Daerah, yayasan, badan hukum, dan perusahaan yang menyertakan modal negara, atau perusahaan yang menyertakan modal pihak ketiga berdasarkan perjanjian dengan negara.

Rumusan tersebut secara substansial pada hakikatnya sama dengan rumusan Pasal 1 angka 1 dan Pasal 2 serta Penjelasan Umum angka 3 Undang-Undang Nomor 17 Tahun 2003 tentang Keuangan Negara.

\section{b. Terminologi Kerugian Keuangan Negara}

Pasal 35 Undang-Undang Nomor 17 Tahun 2003 mengintepretasikan atau menganalogikan "kerugian keuangan negara" sama dengan "kerugian negara", sebagaimana berikut ini:

(1) Setiap pejabat negara dan pegawai negeri bukan bendahara yang melanggar hukum atau melalaikan kewajibannya baik langsung atau tidak langsung yang merugikan keuangan negara diwajibkan mengganti kerugian dimaksud.

(2) Setiap orang yang diberi tugas menerima, menyimpan, membayar, dan/atau menyerahkan uang atau surat berharga atau barang-barang negara adalah bendahara yang wajib menyampaikan laporan pertanggungjawaban kepada Badan Pemeriksa Keuangan.

(3) Setiap bendahara sebagaimana dimaksud dalam ayat (2) bertanggung jawab secara pribadi atas kerugian keuangan negara yang berada dalam pengurusannya.

(4) Ketentuan mengenai penyelesaian kerugian negara diatur di dalam undang-undang mengenai perbendaharaan negara.

Selanjutnya terminologi "kerugian negara" yang digunakan berdasarkan rumusan Undangundang Nomor 1 Tahun 2004 tentang Perbendaharaan Negara Pasal 1 angka 22 adalah bahwa: "kerugian negara/daerah adalah kekurangan uang, surat berharga, dan barang, yang nyata dan pasti jumlahnya sebagai akibat perbuatan melawan hukum baik sengaja maupun 
Jurnal Law Reform

Volume 13, Nomor 2, Tahun 2017
Program Studi Magister Ilmu Hukum Fakultas Hukum Universitas Diponegoro lalai." Dalam Penjelasan Umum angka 6 tentang Penyelesaian Kerugian Negara, ditegaskan bahwa setiap kerugian negara/daerah yang disebabkan oleh tindakan melawan hukum atau kelalaian seseorang harus diganti oleh pihak yang bersalah. Dengan penyelesaian kerugian tersebut negara/daerah dapat dipulihkan dari kerugian yang telah terjadi.

Pasal 59 Undang-Undang Nomor 1 Tahun 2004 tentang Perbendaharaan Negara mengatur tentang Penyelesaian Kerugian Negara/Daerah sebagai berikut:

(1) Setiap kerugian negara/daerah yang disebabkan oleh tindakan melanggar hukum atau kelalaian seseorang harus segera diselesaikan sesuai dengan ketentuan perundangundangan yang berlaku.

(2) Bendahara, pegawai negeri bukan bendahara, atau pejabat lain yang karena perbuatannya melanggar hukum atau melalaikan kewajiban yang dibebankan kepadanya secara langsung merugikan keuangan negara, wajib mengganti kerugian tersebut.

(3) Setiap pimpinan kementerian negara/lembaga/kepala satuan kerja perangkat daerah dapat segera melakukan tuntutan ganti rugi, setelah mengetahui bahwa dalam kementerian negara/lembaga/satuan kerja perangkat daerah yang bersangkutan terjadi kerugian akibat perbuatan dari pihak mana pun.

Selanjutnya Pasal 63 dan 64 UndangUndang Nomor 1 Tahun 2004 tentang Perbendaharaan Negara mengatur hal-hal sebagai berikut:

\section{Pasal 63}

(1) Pengenaan ganti kerugian negara/daerah terhadap pegawai negeri bukan bendahara ditetapkan oleh menteri/pimpinan lembaga/gubernur/ bupati/walikota.

(2) Tata cara tuntutan ganti kerugian negara/daerah diatur dengan peraturan pemerintah.

\section{Pasal 64}

(1) Bendahara, pegawai negeri bukan bendahara, dan pejabat lain yang telah ditetapkan untuk mengganti kerugian negara/daerah dapat dikenai sanksi administratif dan/atau sanksi pidana.

(2) Putusan pidana tidak membebaskan dari tuntutan ganti rugi.

Dalam Hukum Administrasi Negara, rumusan merugikan keuangan negara diinterpretasikan sama dengan kerugian negara. Hal tersebut dapat dilihat pada ketentuan Pasal 35 ayat (1) dan ayat 
Jurnal Law Reform

Volume 13, Nomor 2, Tahun 2017
Program Studi Magister Ilmu Hukum Fakultas Hukum Universitas Diponegoro
(4) Undang-Undang Nomor 17 Tahun 2003 tentang Keuangan Negara; Pasal 1 angka 22, dan Pasal 59 sampai dengan Pasal 67 Undang-undang Nomor 1 Tahun 2004 tentang Perbendaharaan Negara. Ditegaskan lagi dalam Pasal 64 ayat (2) bahwa putusan pidana tidak membebaskan dari tuntutan ganti rugi.

\section{Tata Cara Tuntutan Ganti Kerugian} Negara/Daerah terhadap Pegawai Negeri Bukan Bendahara atau Pejabat Lain

Untuk melaksanakan ketentuan Pasal 63 ayat (2) Undang-Undang Nomor 1 Tahun 2004 tentang Perbendaharaan Negara, maka ditetapkan Peraturan Pemerintah Nomor 38 Tahun 2016 tentang Tata Cara Tuntutan Ganti Kerugian Negara/Daerah terhadap Pegawai Negeri Bukan Bendahara atau Pejabat Lain.

Dalam Peraturan Pemerintah ini, yang dimaksud dengan Tuntutan Ganti Kerugian menurut Pasal 1 angka 2 adalah suatu proses tuntutan yang dilakukan terhadap pegawai negeri bukan bendahara atau pejabat lain dengan tujuan untuk memulihkan Kerugian Negara/Daerah. Selanjutnya menurut angka 3, Pegawai Negeri Bukan Bendahara adalah Pegawai Aparatur Sipil Negara, Anggota Tentara Nasional Indonesia, Anggota Kepolisian Negara Republik Indonesia yang bekerja/diserahi tugas selain tugas bendahara. Sedangkan yang dimaksud dengan Pejabat Lain menurut angka 4 adalah pejabat negara dan pejabat penyelenggara pemerintahan yang tidak berstatus pejabat negara, tidak termasuk bendahara dan Pegawai Negeri Bukan Bendahara. Selanjutnya menurut angka 5, yang dimaksud dengan. Pihak Yang Merugikan adalah Pegawai Negeri Bukan Bendahara atau Pejabat Lain yang berdasarkan hasil pemeriksaan menimbulkan Kerugian Negara/Daerah Bagian Kedua Ruang Lingkup

Pasal 2 ayat (1) Peraturan Pemerintah ini mengatur tata cara Tuntutan Ganti Kerugian Negara/Daerah atas uang, surat berharga, dan/atau barang milik negara/daerah yang ruang lingkupnya berada dalam penguasaan:

a. Pegawai Negeri Bukan Bendahara; atau

b. Pejabat Lain:

1) pejabat negara; dan

2) pejabat penyelenggara pemerintahan yang tidak berstatus pejabat negara, tidak termasuk bendahara dan Pegawai Negeri Bukan Bendahara.

Dalam Penjelasan dinyatakan bahwa ruang lingkup pelaksanaan tuntutan ganti kerugian negara/daerah berlaku bagi semua pegawai negeri bukan bendahara atau pejabat lain yang bertugas di lingkungan instansi pemerintahan Pusat/Daerah dan Lembaga Negara termasuk juga Calon Pegawai Negeri Sipil, serta Pegawai Aparatur Sipil Negara/ anggota TNI/anggota Kepolisian Negara Republik Indonesia yang menjabat sebagai bukan bendahara yang menyebabkan terjadinya kerugian 
Jurnal Law Reform

Volume 13, Nomor 2, Tahun 2017
Program Studi Magister Ilmu Hukum Fakultas Hukum Universitas Diponegoro negara/daerah bukan kekurangan perbendaharaan

( di luar tugas dan fungsi sebagai bendahara).

Yang dimaksud dengan pejabat negara adalah pejabat negara sebagaimana dimaksud dalam Undang-Undang Nomor 5 Tahun 2014 tentang Aparatur Sipil Negara, sebagaimana diatur dalam Pasal 122.

Pejabat penyelenggara pemerintahan yang tidak berstatus pejabat negara adalah ketua dan anggota DPRD sebagai pejabat daerah serta pimpinan dan anggota lembaga non struktural yang dibiayaiAPBN/APBD.

Ayat (2) menyatakan bahwa Tuntutan Ganti Kerugian sebagaimana dimaksud pada ayat (1) berlaku pula terhadap uang dan/atau barang bukan milik negara/daerah yang berada dalam penguasaan Pegawai Negeri Bukan Bendahara atau Pejabat Lain yang digunakan dalam penyelenggaraan tugas pemerintahan.

Pasal 3 ayat (1) Peraturan Pemerintah ini menyatakan bahwa: Setiap Pegawai Negeri Bukan Bendahara atau Pejabat Lain wajib melakukan tindakan pengamanan terhadap:

a. uang, surat berharga, dan/atau barang milik negara/daerah yang berada dalam penguasaannya dari kemungkinan terjadinya Kerugian Negara/Daerah; dan/atau

b. uang dan/atau barang bukan milik negara/daerah yang berada dalam penguasaannya dari kemungkinan terjadinya Kerugian Negara/Daerah.
Selanjutnya ayat (2) menyatakan bahwa Setiap Pegawai Negeri Bukan Bendahara atau Pejabat Lain yang melanggar hukum atau melalaikan kewajibannya baik langsung atau tidak langsung yang merugikan keuangan negara/daerah diwajibkan mengganti kerugian dimaksud.

Pasal 4 Informasi terjadinya Kerugian Negara/Daerah bersumber dari:

a. hasil pengawasan yang dilaksanakan oleh atasan langsung;

b. Aparat Pengawasan Internal Pemerintah;

C. pemeriksaan Badan Pemeriksa Keuangan;

d. laporan tertulis yang bersangkutan;

e. informasi tertulis dari masyarakat secara bertanggung jawab;

f. perhitungan ex officio; dan/atau

g. pelapor secara tertulis.

Pasal 5 ayat (1) menyatakan bahwa Atasan langsung atau kepala satuan kerja wajib melakukan verifikasi terhadap informasi sebagaimana dimaksud dalam Pasal 4. Dalam hal berdasarkan hasil verifikasi ditemukan indikasi kerugian negara/daerah, maka akan ditindaklanjuti berdasarkan ketentuan ayat (3).

Dalam hal Pegawai Aparatur Sipil Negara / Anggota Tentara Nasional Indonesia / Anggota Kepolisian Negara Republik Indonesia / Pejabat 
Lain tidak melaksanakan kewajiban sebagaimana dimaksud dalam Pasal 5 ayat (1), Pasal 5 ayat (2), Pasal 5 ayat (3), dan/atau Pasal 5 ayat (4) dikenakan sanksi administratif sesuai ketentuan peraturan perundang-undangan.

Menurut Pasal 7, berdasarkan laporan hasil verifikasi sebagaimana dimaksud dalam Pasal 5 ayat (3), Pejabat Penyelesaian Kerugian Negara/Daerah (PPKN/D) harus menyelesaikan Kerugian Negara/Daerah dengan melaksanakan Tuntutan Ganti Kerugian.

Pasal 8 ayat (1) menyatakan bahwa PPKN/D sebagaimana dimaksud dalam Pasal 7 adalah sebagai berikut:

a. Menteri/Pimpinan Lembaga, dalam hal kerugian negara dilakukan oleh Pegawai Negeri Bukan Bendahara atau Pejabat Lain di lingkungan Kementerian Negara/Lembaga;

b. Menteri Keuangan selaku Bendahara Umum Negara, dalam hal kerugian negara dilakukan oleh Menteri/Pimpinan Lembaga;

c. Gubernur, Bupati, atau Walikota, dalam hal kerugian daerah dilakukan oleh Pegawai Negeri Bukan Bendahara atau Pejabat Lain di lingkungan Pemerintahan Daerah; atau

d. Presiden, dalam hal Kerugian Negara/Daerah dilakukan oleh Menteri Keuangan selaku Bendahara Umum Negara/Pimpinan Lembaga Negara/Gubernur, Bupati, atau Walikota.
Selanjutnya dalam ayat (2) diatur Kewenangan PPKN/D untuk menyelesaikan Kerugian Negara/Daerah sebagaimana dimaksud pada ayat (1) dilaksanakan oleh:

a. Kepala satuan kerja untuk kerugian negara yang dilakukan oleh Pegawai Negeri Bukan Bendahara atau Pejabat Lain di lingkungan Kementerian Negara/Lembaga sebagaimana dimaksud pada ayat (1) huruf $a$; dan

b. Kepala Satuan Kerja Pengelola Keuangan Daerah selaku Bendahara Umum Daerah untuk kerugian daerah yang dilakukan oleh Pegawai Negeri Bukan Bendahara atau Pejabat Lain di lingkungan Pemerintahan Daerah sebagaimana dimaksud pada ayat (1) huruf c.

Pasal 9 menyatakan bahwa dalam rangka penyelesaian Kerugian Negara/Daerah, PPKN/D sebagaimana dimaksud dalam Pasal 8 ayat (1) atau pejabat yang diberi kewenangan sebagaimana dimaksud dalam Pasal 8 ayat (2), ayat (3), dan ayat (4) membentuk Tim Penyelesaian Kerugian Negara/Daerah (TPKN/TPKD).

Pasal 10 ayat (1) mengatur bahwa TPKN/TPKD melakukan pemeriksaan Kerugian Negara/Daerah paling lambat 7 (tujuh) hari kerja setelah dibentuk. (2) Dalam pemeriksaan Kerugian Negara/Daerah, TPKN/TPKD memiliki tugas dan wewenang: 
a. menyusun kronologis terjadinya Kerugian Negara/Daerah;

b. mengumpulkan bukti pendukung terjadinya Kerugian Negara/Daerah;

c. menghitung jumlah Kerugian Negara/Daerah;

d. menginventarisasi harta kekayaan milik Pegawai Negeri Bukan Bendahara atau Pejabat Lain yang dapat dijadikan sebagai jaminan penyelesaian Kerugian Negara/Daerah; dan

e. melaporkan hasil pemeriksaan kepada pejabat yang membentuknya.

Pasal 14 ayat (1) mengatur tentang Laporan hasil pemeriksaan yang menyatakan bahwa:

a. kekurangan uang, surat berharga, dan/atau barang disebabkan perbuatan melanggar hukum atau lalai Pegawai Negeri Bukan Bendahara atau Pejabat Lain; atau

b. kekurangan uang, surat berharga, dan/atau barang bukan disebabkan perbuatan melanggar hukum atau lalai Pegawai Negeri Bukan Bendahara atau Pejabat Lain.

Selanjutnya ayat (2) menyatakan bahwa Laporan hasil pemeriksaan sebagaimana dimaksud pada ayat (1) huruf a, paling sedikit memuat:

a. pihak yang bertanggung jawab atas terjadinya Kerugian Negara/Daerah; dan

b. jumlah Kerugian Negara/Daerah.
Pasal 15 ayat (1) menyatakan bahwa PPKN/D atau pejabat yang diberi kewenangan sebagaimana dimaksud dalam Pasal 8 ayat (2), ayat (3), dan ayat (4) menyampaikan pendapat atas laporan hasil pemeriksaan TPKN/TPKD sebagaimana dimaksud dalam Pasal 13 ayat (6), sebagai berikut:

a. menyetujui laporan hasil pemeriksaan; atau

b. tidak menyetujui laporan hasil pemeriksaan.

Pasal 16 ayat (1)selanjutnya menyatakan: Dalam hal laporan hasil pemeriksaan sebagaimana dimaksud dalam Pasal 14 ayat (1) huruf a disetujui oleh PPKN/D sebagaimana dimaksud dalam Pasal 15 ayat (1) huruf a, PPKN/D segera menugaskan TPKN/TPKD untuk melakukan penuntutan penggantian Kerugian Negara/Daerah kepada Pihak Yang Merugikan.

Ayat (2) menyatakan: Dalam hal Pihak Yang Merugikan sebagaimana dimaksud pada ayat (1) berada dalam pengampuan, melarikan diri, atau meninggal dunia, penggantian Kerugian Negara/Daerah beralih kepada Pengampu/Yang Memperoleh Hak/Ahli Waris.

Ayat (3) selanjutnya menegaskan bahwa: Dalam penuntutan penggantian Kerugian Negara/Daerah, TPKN/TPKD mengupayakan surat pernyataan kesanggupan dan/atau pengakuan Pihak Yang Merugikan/Pengampu/Yang Memperoleh Hak/Ahli Waris bahwa kerugian tersebut menjadi tanggung jawabnya dan bersedia 
mengganti Kerugian Negara/Daerah dimaksud dalam bentukSurat Keterangan Tanggung Jawab Mutlak (SKTJM).

Ayat (4) menyatakan bahwa SKTJM sebagaimana dimaksud pada ayat (3) paling sedikit memuat:

a. identitas

Pihak

Yang

Merugikan/Pengampu/Yang Memperoleh Hak/Ahli Waris;

b. jumlah Kerugian Negara/Daerah yang harus dibayar;

c. cara dan jangka waktu pembayaran Kerugian Negara/Daerah;

d. pernyataan penyerahan barang jaminan; dan

e. pernyataan dari Pihak Yang Merugikan/Pengampu/Yang Memperoleh Hak/Ahli Waris bahwa pernyataan mereka tidak dapat ditarik kembali.

Selanjutnya ayat (5) menyatakan bahwa Pernyataan penyerahan barang jaminan sebagaimana dimaksud pada ayat (4) huruf d, disertai dengan:

a. daftar barang yang menjadi jaminan;

b. bukti kepemilikan yang sah atas barang yang dijaminkan; dan

c. surat kuasa menjual.

Pasal 17 ayat (1) menyatakan bahwa Penggantian Kerugian Negara/Daerah sebagaimana dimaksud dalam Pasal 16 ayat (1) segera dibayarkan secara tunai atau angsuran.

Ayat (2) selanjutnya mengatur dalam hal Kerugian Negara/Daerah sebagai akibat perbuatan melanggar hukum, Pihak Yang Merugikan/Pengampu/Yang Memperoleh Hak/Ahli Waris wajib mengganti Kerugian Negara/Daerah paling lama 90 (sembilan puluh) hari kalender sejak SKTJM ditandatangani.

Ayat (3) mengatur dalam hal Kerugian Negara/Daerah sebagai akibat kelalaian, Pihak Yang Merugikan/Pengampu/Yang Memperoleh Hak/Ahli Waris wajib mengganti Kerugian Negara/Daerah dalam waktu paling lama 24 (dua puluh empat) bulan sejak SKTJM ditandatangani.

Pasal 18 menyatakan bahwa Dalam hal Pihak Yang Merugikan/Pengampu/Yang Memperoleh Hak/Ahli Waris tidak mengganti kerugian dalam jangka waktu sebagaimana dimaksud dalam Pasal 17 ayat (2), ayat (3), atau ayat (4), Pihak Yang Merugikan/Pengampu/Yang Memperoleh Hak/Ahli Waris dimaksud dinyatakan wanprestasi.

Penyelesaian Kerugian Negara/Daerah melalui Penerbitan Surat Keputusan Pembebanan Penggantian Kerugian Sementara (SKP2KS) dilakukan apabila SKTJM tidak dapat diperoleh (Pasal 19 ayat (1))

Pasal 20 menyatakan bahwa Penggantian Kerugian Negara/Daerah berdasarkan penerbitan 
Jurnal Law Reform

Volume 13, Nomor 2, Tahun 2017
Program Studi Magister Ilmu Hukum Fakultas Hukum Universitas Diponegoro
SKP2KS dibayarkan secara tunai paling lambat 90 (sembilan puluh) hari sejak diterbitkannya SKP2KS.

SKP2KS mempunyai kekuatan hukum untuk pelaksanaan sita jaminan, yang dilakukan oleh instansi yang berwenang melaksanakan pengurusan piutang negara sesuai dengan ketentuan peraturan perundang-undangan (Pasal 21)

Pasal 22 ayat (1) menyatakan bahwa Pihak Yang Merugikan/Pengampu/Yang Memperoleh Hak/Ahli Waris dapat menerima atau mengajukan keberatan SKP2KS paling lambat 14 (empat belas) hari kerja sejak diterimanya SKP2KS.

PPKN/D membentuk Majelis Pertimbangan Penyelesaian Kerugian Negara (Majelis) dalam penyelesaian kerugian negara/daerah berdasarkan Pasal 23 apabila:

a. Sesuai rumusan Pasal 14 ayat (1);

b. Wanprestasi;

c. Penerimaan atau keberatan.

Pasal 25 menyatakan bahwa Majelis mempunyai tugas memeriksa dan memberikan pertimbangan kepada PPKN/D atas: a. penyelesaian atas kekurangan uang, surat berharga, dan/atau barang bukan disebabkan perbuatan melanggar hukum atau lalai Pegawai Negeri Bukan Bendahara atau Pejabat Lain sebagaimana dimaksud dalam 14 ayat (1) huruf b; b. penggantian Kerugian Negara/Daerah setelah Pihak Yang Merugikan/Pengampu/Yang
Memperoleh Hak/Ahli Waris dinyatakan wanprestasi sebagaimana dimaksud dalam Pasal 18; dan c. penyelesaian Kerugian Negara/Daerah yang telah diterbitkan SKP2KS sebagaimana dimaksud dalam Pasal 19 ayat (2).

Menurut Pasal 36, SKP2K yang diterbitkan PPKN/D diterbitkan paling lambat 14 (empat belas) hari kerja sejak Majelis menetapkan putusan hasil sidang sebagaimana dimaksud dalam Pasal 34 ayat (2) dan Pasal 35 ayat (2) huruf a dan huruf $\mathrm{C}$. SKP2K disampaikan kepada:

a. Badan Pemeriksa Keuangan;

b. Majelis; dan

c. Pihak Yang Merugikan/Pengampu/Yang Memperoleh Hak/Ahli Waris. Ayat (5) menyatakan bahwa PPKN/D melakukan pengawasan atas pelaksanaan SKP2K.

Selanjutnya Pasal 37 menegaskan bahwa SKP2K mempunyai hak mendahulu.

Dalam hal penagihan dan penyetoran, Pasal 40 ayat (1) mengatur bahwa Penagihan dalam rangka penyelesaian Kerugian Negara/Daerah dilakukan atas dasar:

a. SKTJM sebagaimana dimaksud dalam Pasal 16 ayat (3);

b. SKP2KS sebagaimana dimaksud dalam Pasal 19 ayat (2); atau

C. SKP2K sebagaimana dimaksud dalam Pasal 36. 
Jurnal Law Reform

Volume 13, Nomor 2, Tahun 2017
Program Studi Magister Ilmu Hukum Fakultas Hukum Universitas Diponegoro
Pasal 41 menyatakan bahwa berdasarkan surat penagihan sebagaimana dimaksud dalam Pasal 40 ayat (2), Pihak Yang Merugikan/Pengampu/Yang Memperoleh Hak/Ahli Waris menyetorkan ganti Kerugian Negara/Daerah ke Kas Negara/Daerah.

Selanjutnya Pasal 42 ayat (1) menyatakan bahwa Pihak Yang Merugikan/Pengampu/Yang Memperoleh Hak/Ahli Waris yang telah melakukan penyetoran ganti Kerugian Negara/Daerah ke Kas Negara/Daerah sesuai dengan jumlah dan jangka waktu yang tercantum dalam SKTJM, SKP2KS, atau SKP2K, dinyatakan telah melakukan pelunasan dengan surat keterangan tanda lunas.

\section{SIMPULAN}

Berdasarkan penelitian yang telah dilakukan, maka dapat disimpulkan bahwa terhadap pegawai negeri bukan bendahara atau pejabat lain dapat dikenai tuntutan ganti kerugian negara/daerah apabila tindakan/perbuatannya dilakukan secara melanggar hukum atau karena kelalaian yang secara langsung menimbulkan kerugian keuangan negara/daerah, sehingga wajib mengganti kerugian tersebut. Tuntutan ganti kerugian tersebut bertujuan untuk memulihkan kerugian negara/daerah. Di ranah Hukum Administrasi Negara hal tersebut diatur dalam Undang-Undang Nomor 17 Tahun 2003, Undang-Undang Nomor 1 Tahun 2004, dan Peraturan Pemerintah Nomor 38 Tahun 2016.
Pegawai negeri bukan bendahara atau pejabat lain yang telah ditetapkan untuk mengganti kerugian negara/daerah dapat dikenai sanksi administratif dan/atau sanksi pidana. Putusan pidana tidak menghapuskan dari tuntutan ganti rugi.

\section{DAFTAR PUSTAKA}

Ginting, Jamin, "Pengertian Merugikan Keuangan Negara dalam Tindak Pidana Korupsi", www.download. portalgaruda.org/article.php ? Diakses tanggal 11 April 2016 pukul 21.45

Hadjon, Philipus. M., 2011, Hukum Administrasi dan Tindak Pidana Korupsi, Yogyakarta: Gadjah Mada University Press

HR, Ridwan, 2013, Hukum Administrasi Negara, Jakarta: PT Raja Grafindo Persada.

Makawimbang, Hernold Ferry, 2014, Kerugian Keuangan Negara, Yogyakarta: Thafa Media

Marbun, SF dan Moh. Mahfud MD, 1987, Pokokpokok Hukum Administrasi Negara, Yogyakarta: Liberty

Ngadino, Agus dan Rumesten, Iza RS, "Pengelolaan Keuangan Negara dalam Perspektif Hukum Administrasi," eprints.unsri.ac.id/2277/1/agus_n_iza_ 05_2012. Diakses 11 April 2016 pukul 21.20 
Jurnal Law Reform

Volume 13, Nomor 2, Tahun 2017
Program Studi Magister Ilmu Hukum Fakultas Hukum Universitas Diponegoro

Saidi, Muhammad Djafar, 2011, Hukum Keuangan Negara, Edisi Revisi, Jakarta: PT Raja Grafindo Persada.

Simatupang, Dian Puji N., 2011, Paradoks Rasionalitas Perluasan Ruang Lingkup Keuangan Negara dan Implikasinya terhadap Kinerja Keuangan Pemerintah, Jakarta: Badan Penerbit FHUI

Soemitro, Ronny Hanitijo, 1994, Metodologi Penelitian Hukum dan Yurimetri, Jakarta: Ghalia Indonesia.

Tjandra, W Riawan, 2008, Hukum Administrasi Negara, Yogyakarta: Penerbit Universtas Atmajaya

Undang-Undang Dasar Negara Republik Indonesia Tahun 1945

Undang-undang Nomor 31 Tahun 1999 jo. Undangundang Nomor 20 Tahun 2001 tentang Pemberantasan Tindak Pidana Korupsi

Undang-Undang Nomor 17 Tahun 2003 tentang Keuangan Negara

Undang-Undang Nomor 1 Tahun 2004 tentang Perbendaharaan Negara

Peraturan Pemerintah Nomor 38 Tahun 2016 tentang Tata Cara Tuntutan Ganti Kerugian Negara/Daerah terhadap Pegawai Negeri Bukan Bendahara atau Pejabat Lain. 